\title{
Correction to: Cladribine Tablets: In Relapsing-Remitting Multiple Sclerosis
}

\author{
Victoria J. Muir ${ }^{1}$. Greg L. Plosker ${ }^{1}$
}

Published online: 9 March 2020

(c) Springer Nature Switzerland AG 2020

\section{Correction to: CNS Drugs 2011; 25(3): 239-249 https://doi.org/10.2165/11204740-00000 0000-00000}

During the creation of the HTML version of the article, incorrect body text (including all tables and figures) and an incorrect Additional Information section were uploaded; the PDF version was correct. The HTML version has now been corrected.

The original article can be found online at https://doi. org/10.2165/11204740-000000000-00000.

Victoria J. Muir

demail@adis.co.nz

1 Adis, a Wolters Kluwer Business, 41 Centorian Drive,

Private Bag 65901, Mairangi Bay, North Shore,

0754 Auckland, New Zealand 